Article

\title{
Higher Pleasures, Civic Virtue, and Democracy: A Reconstruction of Millian Themes
}

\section{J. Mikael Olsson}

\begin{abstract}
This article takes a start in the utilitarian philosophy of John Stuart Mill and considers an interpretation of the concept of "higher pleasures" as referring to "political" pleasures. This interpretation is based on the idea that even if one is a utilitarian, the value of democracy (majority rule) should take precedence over the value of (hedonistic) utilitarianism. On the political level, this has the consequence that civic virtue (or higher pleasures) should have an important role in a democratic society. Thus, the article connects to contemporary discussions on republicanism in a novel way and offers some ideas of how higher pleasures may be promoted in a constitutional context.
\end{abstract}

Keywords: Mill, democracy, utilitarianism, republicanism

\section{Part One}

7 he distinction between higher and lower pleasures (in the context of utilitarian thought) is one of John Stuart Mill's most well-known ideas. However, most readers of Mill have found this distinction unappealing and have concluded that his version of utilitarianism is hard to defend on philosophical grounds. So if one still wants to use the principle of higher and lower pleasures, one has to do a lot of interpretive work, and perhaps also inject some of one's own ideas into the equation. In this article I will put forward my own suggestion of what a reasonable theory of higher pleasures might look like. My contention is that it is possible to be a hedonist of the Benthamite kind (that is, concerned with the maximization of undifferentiated pleasure), yet still adhere to the view that some pleasures should be regarded as "higher" than others. Now this is not simply a case of placing certain pleasures in the higher category because they tend to have more hedonic value than others; it is, rather, a way of appreciating certain 


\section{A RECONSTRUCTION OF MILLIAN THEMES}

pleasures more even though their hedonic values are equal (and in some cases even lower) than other alternatives. This view does, in other words, retain Mill's insistence on a difference in kind (and not just in degree) regarding pleasures, even though it is still basically a hedonistic view. This hedonistic defense of the distinction between higher and lower pleasures becomes possible if we regard certain political "virtues" as being more important than a "simple" felicific calculus would warrant-and this view I believe every utilitarian (hedonistic or otherwise) should hold (why this is so I will explain shortly). This also connects utilitarianism in a fruitful way to some kinds of republicanism; and it is, furthermore, a view that one may find some support for in Mill's own writings. Moreover, I believe the theory put forward in this article provides an answer to a problem frequently raised against utilitarianism, namely, that it does not respect certain fundamental rights. As will become evident, the kind of philosophy defended here does-without being inconsistent-condemn at least some infringements of these allegedly basic rights.

But why, one may ask, bring Mill into the discussion in the first place? Why do I not simply make the argument plain and simple? My answer is that I believe the study of political thinkers of the past helps us to structure certain perennial tensions, especially the one that exists between substantial moral doctrines and forms of political rule. Political thoughts, like those of Mill, are, in other words, helpful as heuristic devices in coming to grips with our own problems. Thus, I have no ambition to find out what Mill "really" thought or what influenced him to think the way he did etc. Mill's political philosophy (or rather parts of it) is simply used (some would perhaps say "shamelessly" used, or distorted) to better clarify an argument. Thus, I am not claiming that the interpretations I make are "superior" to other interpretations. For a long time, many Mill scholars have seen him as being a utilitarian only in a very attenuated sense, or not being a utilitarian at all. ${ }^{1}$ These interpretations are usually made by textual analysis, to find inconsistencies and the like (and it is then assumed that the inconsistencies can be resolved by finding compelling evidence for either side). My endeavor is, however, of a different kind. I am using a "tension" in Mill's thought (mainly his ambiguous account of what utilitarianism is, and how it fits in with the politics in general) to offer ideas that may be of relevance to $u s$, not to Mill himself or to his contemporaries - or, as another theorist has written (in the context of Mill's inconsistencies regarding gender relations): “The tensions in Mill's argument permit us to read him against himself, and widen the path that he opened but was reluctant to follow for whatever reasons." 2

${ }^{1}$ See, e.g., Christopher Miles Coope, “Was Mill a Utilitarian?" in Utilitas, 10:1 (1998).

2 Nancy J. Hirschmann, "Mill, Political Economy, and Women's Work," in American Political Science Review, 102:2 (2008), 211.

(C) 2014 J. Mikael Olsson

http://www.kritike.org/journal/issue 15/olsson december2014.pdf

ISSN 1908-7330

(cc) BY-NC 


\section{Part Two}

Mill's revision of utilitarianism in the little book with the same name is, of course, very well known. To refute the idea that utilitarianism is just a "philosophy for swine," he says that "it is quite compatible with the principle of utility to recognize the fact, that some kinds of pleasure are more desirable and more valuable than others. It would be absurd that while, in estimating all other things, quality is concerned as well as quantity, the estimation of pleasures should be supposed to depend on quantity alone." In the brief discussion leading up to this passage, it is somewhat clear that the pleasures of the intellect are among the higher pleasures, or more specifically, "the pleasures of the intellect, of the feelings and imaginations, and of the moral sentiments." 3

So how do we, in practice, know which specific activities are higher and which are lower? Mill's contention is that to such a question "there is but one possible answer. Of two pleasures, if there be one to which all or almost all who have experience of both give a decided preference, irrespective of any feeling or moral obligation to prefer it, that is the more desirable pleasure." Furthermore, Mill does not hesitate to claim that most people who are acquainted with different kinds of pleasures usually prefer "the manner of existence which employs their higher faculties." This discussion ends with the famous dictum that it is "better to be a human being dissatisfied than a pig satisfied; better to be Socrates dissatisfied than a fool satisfied." 4

Now this notion of competent judges of higher pleasures has been severely criticized over the years. ${ }^{5}$ A recent article by M. Hauskeller may serve to sum up the critique. First, there is the problem of what quality the higher pleasures possess that makes them better than lower pleasures. Mill does not (according to Hauskeller) tell us what "quality" is, and "[ $t]$ o suggest [... ] that intellectual pleasures are more desirable and more valuable because they are of higher quality is like saying that they are more valuable because they are more valuable." 6 Second, there is the problem of finding the supposed competent judges of higher and lower pleasures. Experience seems to show us that virtually all people prefer a life that contains a mix of (what Mill calls) higher and lower pleasures, and that everyone would decline to lead a life that contained only one or the other. This is, however, difficult to

\footnotetext{
${ }^{3}$ John Stuart Mill, Utilitarianism, Liberty, Representative Government (London: J. M. Dent \& Sons, 1954), 7 .

${ }^{4}$ Ibid., $8,9$.

${ }^{5}$ For a brief overview of the criticism, see Henry R. West, An Introduction to Mill's Utilitarian Ethics (Cambridge: Cambridge University Press, 2004), 69-73; also Rex Martin, “A Defence of Mill's Qualitative Hedonism," in Philosophy, 47 (1972), $140 \mathrm{f}$.

${ }^{6}$ Michael Hauskeller, “No Philosophy for Swine: John Stuart Mill on the Quality of Pleasures," in Utilitas, 23:4 (2011), 432.
} 


\section{A RECONSTRUCTION OF MILLIAN THEMES}

square with Mill's claim that the higher pleasures are preferable to the lower irrespective of quantity. ${ }^{7}$ But the problem of competent judges is perhaps even deeper than this because the argument seems to be circular:

We are told that in order to find out what kinds of pleasure are more valuable we need to ask competent judges which they prefer, and when we ask who is a competent judge we are told that competent judges are those, and only those, who prefer the higher kinds of pleasure. ${ }^{8}$

Hauskeller's claim is, in short, that Mill fails to make the argument that utilitarianism is not a "philosophy for swine" because it seems to be difficult to introduce a qualitative distinction between different pleasures without abandoning utilitarianism.

One solution to this dilemma is to introduce higher and lower pleasures as quantitative distinctions only. ${ }^{9}$ It is perfectly possible to be a hedonist and to claim that pleasures can be sorted into different groups according to their pleasantness. Someone like Bentham might, for instance, claim that certain types of pleasure "tend to be intense, but are also rather short-lived, often followed by states of displeasure, and don't give rise to other pleasures so much. In other words, they are deficient with respect to duration, fecundity and purity." 10 And Richard Kirwan, in his 1810 essay Of Happiness, claims that the "savage" state of man is worse because the intellectual pleasures of modern man do, in fact, contain a higher quantity of pleasure, all things considered:

To such mental pleasures as are referable to intellect, memory or imagination, savages have no pretence. And as those sources of pleasure are unproductive of pain, here is one great deficit in the scale of happiness without any counterpoise in pain. ${ }^{11}$

The pleasures of intellect, memory and imagination are, thus, "higher" pleasures in that they contain a larger quantity of pleasure (and on

${ }^{7}$ Ibid., 433-435.

8 Ibid., 438.

${ }^{9}$ Some attempts have actually been made to interpret Mill in this fashion; see mainly H. Keith Quincey, "The Higher Pleasures and their Quantification," in Polity, 12:3 (1980), but also Martin, "A Defence," $146 \mathrm{f}$.

${ }^{10}$ Hauskeller, "No Philosophy for Swine," 440.

${ }^{11}$ Richard Kirwan, "Of Happiness," in Transactions of the Royal Irish Academy, 11 (1810), 132; see also 168-184.

(C) 2014 J. Mikael Olsson http://www.kritike.org/journal/issue 15/olsson december2014.pdf ISSN 1908-7330 
Kirwan's account, this is mainly because they are mixed with pain to a lesser degree than, for example, the pleasures of food or sex).

\section{Part Three}

A utilitarian should agree that it might be valuable to distinguish between different sorts of pleasures on a quantitative scale (although one may, on empirical grounds, quarrel over which pleasures belong in which groups). Nevertheless, this is not the point Mill is making; his distinction between higher and lower pleasures is based on differences in quality-a distinction that appears to be bound to fail (if one wants to remain a hedonist). It is, however, possible to be a fully convinced hedonistic utilitarian while still retaining a qualitative distinction between higher and lower pleasures as long as it is possible to provide that which Mill does not provide: a description of what it is, exactly, that gives the higher pleasures more quality.

One way to make the argument is to make one's utilitarian commitments subservient to one's democratic commitments. Now when democracy is discussed in connection to utilitarianism, the reasoning usually goes the other way around: democracy should be valued as a type of government only insofar as it is the best way to maximize happiness. And this seems to be a reasonable conclusion from utilitarian premises. If a certain minority would derive more pleasure from a change of policy than the majority would from keeping the status quo, then perhaps (or evidently?) we should make the policy change in an undemocratic fashion..$^{12}$

Of course, many of the utilitarians of the early $19^{\text {th }}$ century were more favorably inclined towards democracy than most political thinkers at that time, but there are significant qualifications to their support for democracy. First of all, we should recall that it took quite a while for Bentham to abandon his assumption that utilitarian policies could very well be promoted by enlightened despots (although his support for democracy subsequently became very radical for the time), but apart from this, it is rather well known that James Mill, while being a democrat of sorts, put severe restrictions on voting rights, as did his son, John Stuart (although not as severe as his father's). ${ }^{13}$

What I suggest, however, is that utilitarians (as well as adherents to any other moral doctrine) should let their first allegiance be to democracy, that they should defend democracy (with majority rule and universal suffrage) without qualifications. This is for two reasons (that are lexically

${ }^{12}$ Cf. Quincey, “The Higher Pleasures," 462.

13 See, e.g., Richard W. Krouse, "Two Concepts of Representation: James and John Stuart Mill," in The Journal of Politics, 44 (1982), 513-520; James E. Crimmins, Utilitarian Philosophy and Politics. Bentham's Later Years (London: Continuum, 2011), 30-36, 108-111, 129 f. 


\section{A RECONSTRUCTION OF MILLIAN THEMES}

ordered): (1) utilitarianism is just one of many subjective attitudes one could have, and to presume that utilitarianism should be allowed to override majority rule is just a way of saying that my or my (minority) group should let our subjective preferences rule supreme; (2) the freedom of discussion and inquiry that is a necessary condition of democracy is also very helpful, if not necessary, in finding out what would maximize happiness. (Of course, reason (1) could be rejected by claiming that I (or my small group) should be allowed to rule no matter what, but then we have abandoned the minimal conditions that are needed to speak about political philosophy in any meaningful way. We would simply be in a "state of nature," where people take what they can get without feeling any obligation or desire to give reasons for their actions. This is, again, a possible attitude to take, but it is uninteresting to reflect on in the present context.) In the following I will discuss the (more important) first reason. While reason (2) is more of an internal topic for utilitarians, reason (1) is intended to apply to everyone, regardless of moral doctrine (i.e., no matter what your moral doctrine is, I believe you have good reasons to value democracy above it).

Now reason (1) may make a strong claim upon utilitarians - it says that any notion of objectivity regarding this ethical stance (or, indeed, any ethical stance) should be discarded. In essence, this amounts to saying that non-cognitivism (the belief that norms can be neither true nor false) is the correct view in meta-ethics. Indeed, it is my contention that non-cognitivism is correct. ${ }^{14}$ Furthermore, I argue elsewhere ${ }^{15}$ that non-cognitivism should have some consequences in the context of democracy (namely, that no one should claim that their particular moral view-utilitarianism, for instanceshould be implemented unless a majority supports it). It seems highly reasonable to me that non-cognitivism should inculcate some humility into its adherents, or as one philosopher has put it:

An emotivist [who would usually also be a noncognitivist] need not adopt all contrary ideals [ ... ]. All he must do is recognize that there are contrary ideals and that, while in his terms these ideals are evil, his ideals are evil in their terms. And that, except in terms of somebody's ideal, neither ideal is right. ${ }^{16}$

\footnotetext{
${ }^{14}$ For a brief defense of non-cognitivism, see J. Mikael Olsson, Austrian Economics as Political Philosophy (Dissertation, forthcoming), chapter I.

${ }^{15}$ J. Mikael Olsson, "The Straussian Paradigm Turned Upside-Down: A Model for Studying Political Philosophy," in Minerva - An Internet Journal of Philosophy, 17 (2013); "Plato, Socrates, and the Politics of Meta-Aggression," in SATS. Northern European Journal of Philosophy, 14:2 (2013).

16 Asher Moore, "Emotivism: Theory and Practice," in The Journal of Philosophy, 55:9 (1958), $379 \mathrm{f}$

(C) 2014 J. Mikael Olsson

http://www.kritike.org/journal/issue 15/olsson december2014.pdf

ISSN 1908-7330

(cc) BY-NC
} 
Just ponder what it would be like to reject these sentiments; either we must reject non-cognitivism and claim that there are objectively correct answers to what is right and wrong, or we must become radical egoists and claim that one is allowed to have one's will realized (in various social contexts) simply because it is my will or my attitude that is being expressed (i.e., that the fact that $I$, Mr. or Ms. So-and-so, have a moral attitude makes that attitude more right than everyone else's and should thus be implemented by law).

Regarding reason (2), it may be argued that it is an empirical matter that remains to be confirmed (a fan of B. F. Skinner's fictional utopia Walden Two might, for instance, claim that "politics" is unnecessary for the pursuit of happiness, and that the important thing is to have expert managers, be they elected democratically or not). However, since the argument about putting democracy "above" utilitarianism stands firm in spite of a refutation of reason (2), I will not discuss it further.

\section{Part Four}

If we then accept that we, as (hedonistic) utilitarians, must respect the democratic procedure, we may at the same time have to view some kind of pleasures as "higher," in that they are in some ways connected to this procedure. We may, in other words, view the higher pleasures as political pleasures-or perhaps as civic virtues. These higher pleasures may then be regarded as qualitatively different from, as well as more valuable than, the lower pleasures, but we will still be able to be quantitative hedonists when it comes to "substantial" decisions, that is, decisions that do not concern the democratic framework. In other words, when it comes to constitutional questions (as well as "ordinary" laws that have more or less obvious indirect impact on the democratic constitution), the notion of higher pleasures comes into full force, but the less actual laws (or acts of private individuals) affect the democratic framework, the less we have to take account of higher pleasures in our utilitarian reasoning. (This also means that we cannot, for instance, disenfranchise certain citizens or suppress their freedom of speech in the name of higher quantities of pleasure because if we want to value democracy above any substantial moral doctrine, then we must surely insist on these absolute rights that are necessary for the functioning of a democracy.)

This line of thinking makes an interesting bridge between utilitarianism and republicanism. Now republicanism comes in different forms, and I suspect that my ideas are less compatible with some of the "instrumental" theories of republicanism that have surfaced in recent 


\section{A RECONSTRUCTION OF MILLIAN THEMES}

decades than with more "procedural" theories (Philip Pettit's republican theory, for instance, would not be very compatible with the view of civic virtue propounded in the present article since he believes (majoritarian) democratic politics may itself become a threat to freedom from domination ${ }^{17}$ ). Since I suggested that we should value democracy before any substantial moral theory, it may be the case that we should mainly look back to (what we may call) the Greek virtues of participation rather than the Roman defense of republican rule because the former stresses the value of participation in itself, whereas the Roman tradition stresses participation in order to safeguard freedom for the individual. The two traditions seem, however, to share a lot of common features. For one thing, the (individual) practice of these kinds of republicanism seems similar. ${ }^{18}$ It is important for the citizens to be publicspirited and to "be prepared to overcome their personal inclinations and set aside their private interests when necessary and to do what is best for the public as a whole." Civic virtue is the "lifeblood" of the republic, and "[w]ithout citizens who are willing to defend the republic against foreign threats and to take an active part in government," it will fail. ${ }^{19}$

In light of this, it is interesting that while Mill is rather silent when it comes to specific examples of higher pleasures (specific examples are mostly invented by interpreters of Mill), ${ }^{20}$ he does, nevertheless, hold civic virtue in high esteem. Indeed, his view of democratic rule seems to rely more on the "quality" of the people than of the institutions, believing that "[i]f representative government" and "social life in general is to attain a full, vigorous, many-sided development [ ... ] it will depend upon the free selfrealisation of individual men who say the thing they think and act the thing they say." ${ }^{21}$ It is well known that he writes about the value of deliberation and free inquiry (which are no doubt important to the virtuous citizen) in his essay On Liberty, but a fuller account of civic virtues may be found in Considerations on Representative Government. It seems to be only in this work that we get an idea of what a person devoted to the higher pleasures would look like, or, more specifically, how such a person would act in the political realm. One main point in Considerations is that the "political machinery does not act in itself," so it needs active participation by its members:

17 Philip Pettit, Republicanism. A Theory of Freedom and Government (Oxford University Press, 1997), 62, 180-183, 200 f, 232.

${ }^{18}$ Cf. Shelley Burtt, "The Good Citizen's Psyche: On the Psychology of Civic Virtue," in Polity, 23:1 (1990), 23.

19 Richard Dagger, "Communitarianism and Republicanism," in G. Gaus \& C. Kukathas eds., Handbook of Political Theory (London: SAGE, 2004), 169, 170.

${ }^{20}$ Cf. John McCunn, Six Radical Thinkers (London: Edward Arnold, 1910), 85: "If there be a compact and connected ideal of happiness discoverable in Mill's writings, the reader is left to piece it together for himself."

${ }^{21}$ Ibid., $44 \mathrm{f}$.

(C) 2014 J. Mikael Olsson

http://www.kritike.org/journal/issue 15/olsson december2014.pdf

ISSN 1908-7330

(cc) BY-NC 
The people for whom the [representative] form of government is intended $[\ldots]$ must be willing and able to do what is necessary to keep it standing. And they must be willing and able to do what it requires of them to enable it to fulfil its purposes. [ ... ] [A] people may prefer a free government, but if, from indolence, or carelessness, or cowardice, or want of public spirit, they are unequal to the exertions necessary for preserving it $[\ldots]$ they are more or less unfit for liberty.22

Mill wrote a lot about this sort of thing, namely, how people should act to preserve their free government. He does not generally discuss the virtues of the "private" person (which even Bentham did at times), but he discusses the virtues of the "public" person a lot. So even if his account of utilitarianism is rather vague, he still lets us know what he means by a virtuous, public-spirited human being. In a couple of pages in Considerations, he lists "qualities" like industry, integrity, justice, and prudence, as well as "attributes" like mental activity, enterprise, originality, invention, and courage, as necessary for a (basically) democratic government. ${ }^{23}$ These are similar qualities and attributes that we also meet in Utilitarianism as examples of higher pleasures, but in Considerations, we see clearer the political relevance of these virtues. In other words, if we do not get a good reason in the former work what makes the higher pleasures good, we get-at least potentiallythat reason in the latter. The higher pleasures seem to be very much similar to the activities one might plausibly think are necessary to keep a democratic government going.

If we, moreover, turn back to the republican theme, we actually see a strong "Periclean" streak in Mill's writings. Not only does he (in On Liberty) mention Pericles by name as an outstanding ideal, but he does also talk positively about the Athenian model of political participation: "Notwithstanding the defects of the social system and moral ideals of antiquity, the practice of the dicastery and the ecclesia raised the intellectual standard of an average Athenian far beyond anything of which there is yet an example of in any other mass of men, ancient or modern." 24 In other words, the Athenian constitution may have given its citizens ample opportunities to experience higher pleasures, and most of those citizens would probably think that these higher pleasures (so necessary for their political system) should

\footnotetext{
${ }^{22}$ Mill, Representative Government, $177 \mathrm{f}$.

${ }^{23}$ Ibid., $187 \mathrm{f}$.

${ }^{24}$ Ibid., 216. Cf. Frederick Rosen, Classical Utilitarianism from Hume to Mill (London: Routledge, 2003), $295 \mathrm{f}$.
} 


\section{A RECONSTRUCTION OF MILLIAN THEMES}

take precedence over the advancement of pleasures that have no effect on the constitution (or may actually be detrimental to it, if they were given free rein).

Now it is evident that Mill did not, in fact, value the procedure of democracy in itself. He held that the purpose of government is to make people better in some ways and to advance civilization, and some form of democracy (or "representative government") may be the most appropriate means to this at a certain stage of history. ${ }^{25}$ This is the main point where the present theory differs from Mill's actual theory of democracy. Nevertheless, the qualities that Mill sees as desirable in a "civilized" and "progressed" human being seem to be basically the same qualities as those required for a proceduralist view (i.e., a view where the procedure is valuable in itself, and the qualities needed to keep this procedure going are valuable as means only). But this also highlights the need to judge my theory, so to speak, on its own merits, and not according to a criteria of correctness of interpretation and the like.

\section{Part Five}

I have suggested that even a hedonistic utilitarian can (and should) accept a notion of higher pleasures as "political" pleasures, since devotion to (the procedure) of democracy should precede substantial moral considerations. Now we have also seen that traces of this "republican" utilitarianism can be found in Mill too, and it is an interpretation (or perhaps a creative reconstruction) of his argument that has the potential to be more inspiring to us than his rather cryptic account of higher pleasures in Utilitarianism. Furthermore, I do think that this republican utilitarianism is a highly reasonable political philosophy to subscribe to (whether Mill subscribed to it or not). In practice, it provides us a heuristic device for such purpose as to allocate public resources, whereby we can be guided by considerations of higher and lower pleasures. With this theory, we have a reason why we may use the political machinery to produce more dissatisfied Socrates-like people than satisfied fools, why we, even as utilitarians, may promote civic virtue, "understood as the disposition to give public ends precedence over private desires in both political action and deliberation." 26 And once we have secured a viable state of majority rule, as well as a willingness "to do what is necessary to keep it standing," we may revert to a greater extent to a full consideration of the "lower" pleasures in the actual lawmaking process. This would mean, perhaps, that a democratic society should provide ample opportunities for education and public debate (for

${ }^{25}$ Henry M. Magid, “John Stuart Mill," in L. Strauss \& J. Cropsey eds., History of Political Philosophy, $3^{\text {rd }}$ ed. (The University of Chicago Press, 1987).

${ }^{26}$ Burtt, "The Good Citizen's Psyche," $35 \mathrm{f}$.

(C) 2014 J. Mikael Olsson

http://www.kritike.org/journal/issue 15/olsson december2014.pdf

ISSN 1908-7330

(cc) BY-NC 
instance, through the funding of research in a wide variety of fields as well as of public service media), even if the resources that are necessary for this must be redirected from projects that mainly concern "material" growth (beyond reasonable minimum levels) or the like.

I will end by mentioning a few possible objections to my reasoning. First, there is the premise that one should not base the value of democracy on one's own substantive moral theory. Now I have assumed, in a quite "populist" fashion (to use Robert Dahl's terminology), that "in choosing among alternatives, the alternative preferred by the greater number is selected." 27 This could be challenged by claiming - as James Madison did, for instance - that it is not the size of the majority that matters; it is "whether the ruling group, whatever its size, imposes severe deprivations on the 'natural rights' of citizens." ${ }^{28}$ Of course, one can substitute one's own cherished moral doctrine for natural rights, but my contention is that whatever that doctrine is, one should not make one's defense of democracy dependent on it. To do so would be either to claim that there are some kinds of objective moral facts, or that political rule is just about asserting your personal value preferences (and unless democracy realizes your personal value preferences, then some other kind of rule would be preferable). As a non-cognitivist and anti-realist (believing that there are no moral norms that can be true or false and that there are no moral facts), I must dismiss the first point. To defeat my dismissal would require a successful defense of moral realism and cognitivism.

As to the view that political rule is a completely egoistical affair, I can only admit that my theory would crumble (for an "egoistic" utilitarian this would mean that the value of democracy is dependent on the fact that utilitarianism, according to him or her, is the best moral theory, and if a majority of the people are not utilitarians, then it would be okay to override that majority for no other reason than that the majority is violating his or her personal preference for utilitarianism). In that case, however, we have abandoned all meaningful political philosophy anyway, and a fundamental existential condition of mankind is that we always have the option to refuse to philosophize or to present reasons for our actions. As for myself, I believe that the only non-egoistical way (or perhaps the least egoistical way we can think of) to defend democracy is to let the majority rule simply because it is the majority, by virtue of our fundamental equality on the metaethical plane (i.e., we are all equal in that no one's moral preference is more "true" than anyone else's). And if the majority is not advocating hedonistic utilitarianism, one should not insist that it be implemented anyway (we should not, in other words, set up a constitution that, for example, demands qualified majorities

${ }^{27}$ Robert A Dahl, A Preface to Democratic Theory (University of Chicago Press, 2006), 64.

${ }^{28}$ Ibid., 10. 


\section{A RECONSTRUCTION OF MILLIAN THEMES}

for legislation that is not clearly based on hedonistic considerations - of course, this also excludes more drastic ways of enforcing minoritarian policies, such as enacting a coup d'état and setting up a dictatorship), but one should insist that everyone appreciate the virtues (i.e., higher pleasures) that are necessary to produce a well-functioning democracy. To accept majority rule but deny that any surrounding institutions and practices are necessary to keep it going seems to be highly inconsistent (but for a discussion on the purely empirical side of this argument, see below).

Another objection is that the view discussed here confuses the meaning of "pleasures." When we discuss pleasures as civic virtues we are obviously talking about an activity (the exercising of civic virtue), whereas as hedonists we are talking about mental states (the experience of "actual" pleasures). To unify these different kinds of consequences into a single theory may be problematic. I accept that it may be confusing to speak about "pleasures" on both levels-the constitutional (focused on political "pleasures") and the regular lawmaking level (focused on hedonistic "pleasures") - and that the theory may necessitate some "inflation" of the meaning of the word "pleasure." I believe, however, that it is possible to keep this term, provided that we are clear in each case which level we are referring to. But to be clear, I am arguing that it is the pleasures that come from political activities that should be regarded as higher. Thus, political activities themselves should not be equated with higher pleasures, nor should civic virtue be equated with higher pleasures-again, it is the pleasures produced by the exercise of civic virtue that are important when it comes to distinguishing between higher and lower pleasures. This ought to mean that someone who is forced to exercise civic virtue, and who is not enjoying it one bit, cannot be said to add to the sum of higher pleasures in society. What it does mean, on the other hand, is that if people who would enjoy it have no possibilities to do it (for instance, because they are too poor and have no access to education), then the sum of higher pleasures would seem to be less than it could potentially be.

Lastly, let us look at a possible empirical objection, namely, that the functioning of a healthy democracy does not depend very much on the things I have labeled as higher pleasures, that democracy can be well sustained without virtuous and well-informed citizens. I will not try to evaluate the empirical research on these matters, but I will concede that if this objection is well founded, then there seems to be no weighty reasons for a utilitarian to lay much stress on the higher pleasures. In that case it would be best to be simply a classical hedonist (and, of course, a democrat). But many social scientists (as well as other kinds of scholars) do not believe that the objection is well founded. Personally, I think there is something to Martha Nussbaum's assertion that something has gone wrong in our time when it comes to

(C) 2014 J. Mikael Olsson

http://www.kritike.org/journal/issue 15/olsson december2014.pdf

ISSN 1908-7330

(cc) BY-NC 
preparing people for democracy. Writes Nussbaum: “Thirsty for national profit, nations, and their systems of education, are heedlessly discarding skills that are needed to keep democracies alive. If this trend continues, nations all over the world will soon be producing generations of useful machines, rather than complete citizens who can think for themselves, criticize tradition, and understand the significance of another person's sufferings and achievements." ${ }^{29}$ Nussbaum is, of course, not a utilitarian, but what are the "skills" she is talking about other than things that Mill would call higher pleasures? ${ }^{30}$

Department of Political Science, Stockholm University, Sweden

\section{References}

Brink, David, "Mill's Deliberative Utilitarianism," in Philosophy and Public Affairs, 21:1 (1992).

Burtt, Shelley, "The Good Citizen's Psyche: On the Psychology of Civic Virtue," in Polity, 23:1 (1990).

Crimmins, James E., Utilitarian Philosophy and Politics. Bentham's Later Years (London: Continuum, 2011).

Coope, Christopher Miles, “Was Mill a Utilitarian?" in Utilitas, 10:1 (1998).

Dagger, Richard, "Communitarianism and Republicanism," in G. Gaus \& C. Kukathas eds., Handbook of Political Theory (London: SAGE, 2004).

Dahl, Robert A., A Preface to Democratic Theory (University of Chicago Press, 2006).

Hauskeller, Michael, "No Philosophy for Swine: John Stuart Mill on the Quality of Pleasures," in Utilitas, 23:4 (2011).

Hirschmann, Nancy J., "Mill, Political Economy, and Women's Work," in American Political Science Review, 102:2 (2008).

Kirwan, Richard, "Of Happiness," in Transaction of the Royal Irish Academy, 11 (1810).

Krouse, Richard W., “Two Concepts of Representation: James and John Stuart Mill," in The Journal of Politics, 44 (1982).

Magid, Henry M., “John Stuart Mill”, in L. Strauss \& J. Cropsey eds., History of Political Philosophy, $3^{\text {rd }}$ ed. (The University of Chicago Press, 1987).

Martin, Rex, "A Defence of Mill's Qualitative Hedonism," in Philosophy, 47 (1972).

McCunn, John, Six Radical Thinkers (London: Edward Arnold, 1910).

${ }^{29}$ Martha Nussbaum, Not for Profit. Why Democracy Needs the Humanities (Princeton University Press, 2010), 2.

${ }^{30}$ Cf. David Brink, "Mill's Deliberative Utilitarianism," in Philosophy and Public Affairs, 21: 1 (1992), 101

(c) 2014 J. Mikael Olsson

http://www.kritike.org/journal/issue 15/olsson december2014.pdf

ISSN 1908-7330 


\section{A RECONSTRUCTION OF MILLIAN THEMES}

Mill, John Stuart, Utilitarianism, Liberty, Representative Government (London: J. M. Dent \& Sons, 1954).

Moore, Asher, "Emotivism: Theory and Practice," in The Journal of Philosophy, 55:9 (1958).

Nussbaum, Martha, Not For Profit. Why Democracy Needs the Humanities (Princeton University Press, 2010).

Olsson, J. Mikael, Austrian Economics as Political Philosophy, forthcoming dissertation.

Olsson, J. Mikael, "Plato, Socrates, and the Politics of Meta-Aggression," in SATS. Northern European Journal of Philosophy, 14:2 (2013).

Olsson, J. Mikael, “The Straussian Paradigm Turned Upside-Down. A Model for Studying Political Philosophy," in Minerva - An Internet Journal of Philosophy, 17 (2013).

Pettit, Philip, Republicanism. A Theory of Freedom and Government (Oxford University Press, 1997).

Quincey, H. Keith, "The Higher Pleasures and their Quantification," in Polity, 12:3 (1980).

Rosen, Frederick, Classical Utilitarianism from Hume to Mill (London: Routledge, 2003).

West, Henry R., An Introduction to Mill's Utilitarian Ethics (Cambridge University Press, 2004).

(c) 2014 J. Mikael Olsson

http://www.kritike.org/journal/issue 15/olsson december2014.pdf

ISSN 1908-7330 